Article

\title{
Preparation and characterization of Ni-Ti-O mixed oxide for selective catalytic reduction of NO under lean-burn conditions
}

\author{
YUAN Deling, LI Xinyong*, ZHAO Qidong \\ School of Environmental Science and Technology, State Key Laboratory of Fine Chemical, Key Laboratory of Industrial Ecology and Environmental \\ Engineering of Ministry of Education, Dalian University of Technology, Dalian 116024, Liaoning, China
}

\section{A R T I C L E I N F O}

Article history:

Received 27 February 2013

Accepted 10 May 2013

Published 20 July 2013

\section{Keywords:}

Ni-Ti-O mixed oxide

Selective catalytic reduction

Nitrogen monoxide

Propene

\begin{abstract}
A B S T R A C T
A novel Ni-Ti-O mixed-oxide catalyst was prepared by a homogeneous coprecipitation method and tested in the selective catalytic reduction of $\mathrm{NO}$ by propene $\left(\mathrm{C}_{3} \mathrm{H}_{6}-\mathrm{SCR}\right)$ in the presence of excess $\mathrm{O}_{2}$. Catalysts with different molar ratios of $\mathrm{Ni}$-Ti were characterized using X-ray diffraction, $\mathrm{N}_{2}$ adsorption-desorption, pyridine adsorption, temperature-programmed desorption, and in-situ Fourier-transform infrared spectroscopy. The $\mathrm{Ni}_{1} \mathrm{Ti}_{1}$ catalyst showed good activity in $\mathrm{C}_{3} \mathrm{H}_{6}-\mathrm{SCR}$ at $430{ }^{\circ} \mathrm{C}$ and the $\mathrm{NO}_{x}$ conversion achieved $68 \%$. This catalyst displayed an anatase structure and had a high surface area $\left(149 \mathrm{~m}^{2} / \mathrm{g}\right)$, which is helpful to enhance the catalyst activity. Lewis acid sites were beneficial for adsorbing nitrate, which was the main intermediate produced during the SCR of NO by $\mathrm{C}_{3} \mathrm{H}_{6}$.
\end{abstract}

(C) 2013, Dalian Institute of Chemical Physics, Chinese Academy of Sciences. Published by Elsevier B.V. All rights reserved.

\section{Introduction}

With the fast development of the automobile industry and the rapid increase in the number of automobiles, increasing attention is being paid to pollution by nitrogen oxides $\left(\mathrm{NO}_{x}\right)$ from vehicle exhaust gases. High-efficiency lean-burn engines can significantly reduce energy consumption and have good potential for applications [1]. However, the exhaust of a lean-burn engine contains a large quantity of $\mathrm{O}_{2}$, which can reduce the activities of traditional three-way catalysts [2]. The development of new catalysts that can effectively remove $\mathrm{NO}_{x}$ under conditions of excess $\mathrm{O}_{2}$ is therefore of great theoretical and practical significance.

The selective catalytic reduction (SCR) of NO by hydrocarbons is considered to be one of the most effective methods of controlling NO emissions by motor vehicles [3]. Moreover, this method does not need the addition of any exogenous reducing agents, so it has great potential in development and applica- tions. Previous research has shown that Ni-based catalysts have activities for SCR of NO by hydrocarbons, and Ni is used as an active component of catalytic systems [4]. Titanium dioxide $\left(\mathrm{TiO}_{2}\right)$ has been widely used as a catalyst supporting material for SCR of NO because of its competitive cost and low toxicity [5]. Combining the virtues of Ni-based catalysts and $\mathrm{TiO}_{2}$, we prepared a Ni-Ti-O mixed-oxide catalyst using a urea homogeneous coprecipitation method and tested it in SCR of NO by $\mathrm{C}_{3} \mathrm{H}_{6}$ in the presence of excess $\mathrm{O}_{2}$ and explored the relationship between catalyst structure and catalytic performance.

\section{Experimental}

\subsection{Catalyst preparation}

The Ni-Ti-O mixed-oxide catalysts were prepared by homogeneous coprecipitation. $\mathrm{Ni}\left(\mathrm{NO}_{3}\right)_{2} \cdot 6 \mathrm{H}_{2} \mathrm{O}$ and $\mathrm{Ti}\left(\mathrm{SO}_{4}\right)_{2}$ were mixed with deionized water to obtain salt solutions with ionic

\footnotetext{
*Corresponding author. Tel/Fax: +86-411-84707733; E-mail: xyli@dlut.edu.cn This work was supported by the National Natural Science Foundation of China $(21250110513,51178076)$. 
ratios of $\mathrm{Ni} / \mathrm{Ti}=0.5,1,2$, and 3 , which were denoted as $\mathrm{Ni}_{1} \mathrm{Ti}_{2}$, $\mathrm{Ni}_{1} \mathrm{Ti}_{1}, \mathrm{Ni}_{2} \mathrm{Ti}_{1}$ and $\mathrm{Ni}_{3} \mathrm{Ti}_{1}$. The salt solution and a urea solution (salt ions/urea $=3.3$ ) were added to a beaker and stirred at 90 ${ }^{\circ} \mathrm{C}$ for $48 \mathrm{~h}$. All the precipitates were centrifuged, washed, and dried at $70{ }^{\circ} \mathrm{C}$ for $24 \mathrm{~h}$. The resulting precursors were calcined at $450{ }^{\circ} \mathrm{C}$ for $6 \mathrm{~h}$ to give the $\mathrm{Ni}-\mathrm{Ti}-\mathrm{O}$ mixed-oxide catalysts.

\subsection{Catalyst tests}

$\mathrm{C}_{3} \mathrm{H}_{6}$-SCR activity tests over the catalysts were carried out in a fixed-bed quartz reactor with an inner diameter of $6 \mathrm{~mm}$, containing $0.2 \mathrm{~g}$ of catalyst. The feed gas compostions were $0.1 \% \mathrm{NO}, 0.1 \% \mathrm{C}_{3} \mathrm{H}_{6}$, and $10 \% \mathrm{O}_{2}$ in balance He. The total flow rate was $100 \mathrm{ml} / \mathrm{min}$. The $\mathrm{N}_{2}$ and $\mathrm{C}_{3} \mathrm{H}_{6}$ in the off-gas were detected by gas chromatography (Techcomp 7980II). The concentration of $\mathrm{N}_{2}$ was analyzed using a $5 \mathrm{~A}$ zeolite column with a thermal conductivity detector, and $\mathrm{C}_{3} \mathrm{H}_{6}$ was analyzed using a 6DX-104 column with a flame ionization detector. The concentrations of $\mathrm{NO}$ and $\mathrm{NO}_{2}$ were determined using a Testo 350 gas analyzer. The $\mathrm{N}_{2} \mathrm{O}$ yield was calculated as the $\mathrm{NO}$ conversion minus the $\mathrm{N}_{2}$ and $\mathrm{NO}_{2}$ yields.

\subsection{Catalyst characterization}

X-ray diffraction (XRD) patterns of the samples were obtained using a LabX-6000 X-ray powder diffractometer (Shimadzu) with a $\mathrm{Cu} K_{\alpha}$ radiation source $(\lambda=0.154056 \mathrm{~nm})$ and $2 \theta$ scan rate of $5 \% / \mathrm{min}$ from $10^{\circ}-80^{\circ}$. The Brunauer-Emmett-Teller (BET) surface areas and the Barrett-Joyner-Halenda pore diameters of the catalysts were determined using a NOVA 4200 automated gas sorption analyzer (Quantachrome) through the $\mathrm{N}_{2}$ adsorption equilibria at -198 ${ }^{\circ} \mathrm{C}$. The acidities of the catalysts were determined from chemisorbed pyridine using a Bruker VERTEX 70 Fourier-transform infrared (FTIR) spectrometer. The catalysts (0.02 g) were pressed into wafers and heated in a vacuum at $400{ }^{\circ} \mathrm{C}$ for $1 \mathrm{~h}$. After the system had cooled to room temperature, the catalysts were saturated with pyridine vapor for $20 \mathrm{~min}$ and then stabilized for $30 \mathrm{~min}$. The desorption of pyridine was carried out by evacuation at $200{ }^{\circ} \mathrm{C}$, and FTIR spectra were recorded.

\subsection{Temperature-programmed desorption (TPD) and in-situ FTIR}

$\left(\mathrm{NO}+\mathrm{O}_{2}\right)$-TPD experiments were carried out in a fixed-bed reactor, and the effluent gases were detected using an on-line quadrupole mass spectrometer (Ametek, LC-D200M). Prior to the experiments, the catalysts $(0.1 \mathrm{~g})$ were pretreated in $\mathrm{He}$ at $250{ }^{\circ} \mathrm{C}$ for $1 \mathrm{~h}$. After cooling to room temperature, the catalysts were treated in a flow of $0.25 \% \mathrm{NO}+25 \% \mathrm{O}_{2} / \mathrm{He}$ at $25{ }^{\circ} \mathrm{C}$ for 1 $\mathrm{h}$ and flushed with He for $1 \mathrm{~h}$ to remove physically adsorbed molecules. Finally, the TPD process was carried out at a heating rate of $10^{\circ} \mathrm{C} / \mathrm{min}$ up to $650{ }^{\circ} \mathrm{C}$.

In-situ FTIR experiments were conducted using a VERTEX 70-FTIR spectrometer. Before performing the experiments, the catalysts $(0.02 \mathrm{~g}$ pressed into wafers) were treated in He at 400 ${ }^{\circ} \mathrm{C}$ for $1 \mathrm{~h}$. The total flow rate was $40 \mathrm{ml} / \mathrm{min}$.

\section{Results and discussion}

\subsection{Catalyst activity}

The Ni-Ti-O mixed-oxide catalysts were tested in $\mathrm{C}_{3} \mathrm{H}_{6}-\mathrm{SCR}$ under lean-burn conditions; the results are shown in Fig. 1. The $\mathrm{NO}_{x}$ conversion increased with increasing reaction temperature to a maximum and then decreased, whereas $\mathrm{C}_{3} \mathrm{H}_{6}$ conversion increased until oxidation was complete. The reaction temperature of the maximum $\mathrm{NO}_{x}$ conversion was close to that for complete consumption of $\mathrm{C}_{3} \mathrm{H}_{6}$, indicating that the drop in $\mathrm{NO}_{x}$ conversion with increasing temperature could be caused by lack of reductant. The $\mathrm{Ni}_{1} \mathrm{Ti}_{1}$ catalyst displayed the optimal catalytic activity, i.e., the highest $\mathrm{NO}_{x}$ conversion, the best selectivity for $\mathrm{N}_{2}$, and the largest operating-temperature window.

\subsection{Catalyst characterization results}

The XRD patterns of the catalysts are shown in Fig. 2. For the $\mathrm{Ni}_{1} \mathrm{Ti}_{2}$ and $\mathrm{Ni}_{1} \mathrm{Ti}_{1}$ catalysts, diffraction peaks at $2 \theta \approx 25.28^{\circ}$, $37.80^{\circ}, 48.05^{\circ}, 55.06^{\circ}, 62.69^{\circ}, 68.76^{\circ}$ and $75.03^{\circ}$, attributed to anatase were detected. With increasing $\mathrm{Ni}$ content to $\mathrm{Ni}_{2} \mathrm{Ti}_{1}$ and $\mathrm{Ni}_{3} \mathrm{Ti}_{1}$, two additional peaks at $37.24^{\circ}$ and $43.36^{\circ}$ appeared. These were ascribed to nickel oxide and nickel titanate, respectively. These results imply that the $\mathrm{Ni}_{2} \mathrm{Ti}_{1}$ and $\mathrm{Ni}_{3} \mathrm{Ti}_{1}$ catalysts consist mainly of anatase and small amounts of nickel oxide and nickel titanate. It is noteworthy that anatase is the major

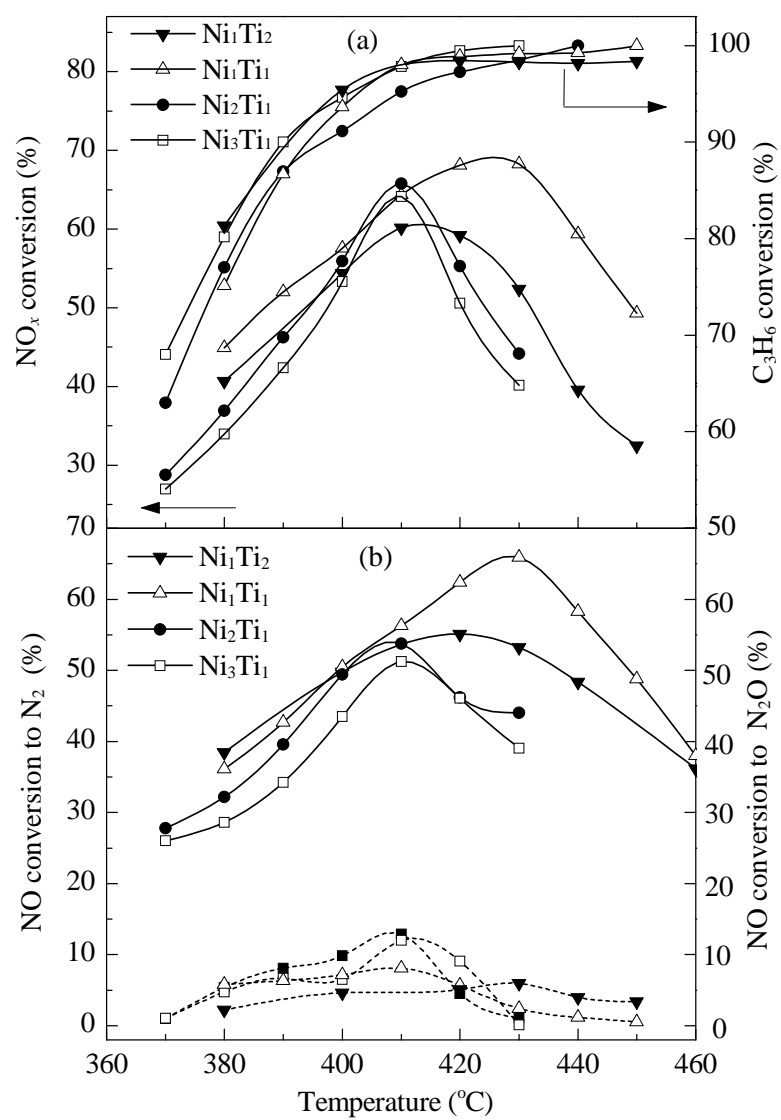

Fig. 1. Catalytic performance of Ni-Ti-O mixed-oxide catalysts for $\mathrm{C}_{3} \mathrm{H}_{6}$-SCR. Reaction conditions: $0.1 \% \mathrm{NO}, 0.1 \% \mathrm{C}_{3} \mathrm{H}_{6}, 10 \% \mathrm{O}_{2}$ in balance He. 


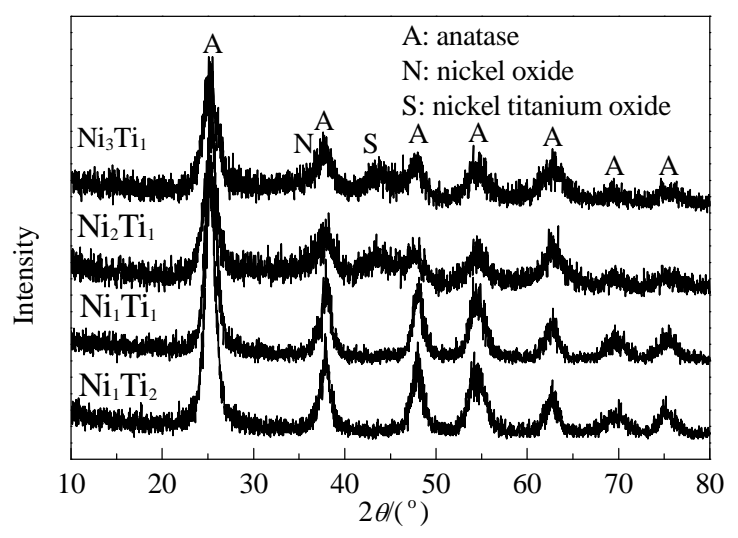

Fig. 2. XRD patterns of Ni-Ti-O mixed-oxide catalysts.

structure in these Ni-Ti-O mixed-oxide catalysts with continuously increasing amounts of $\mathrm{Ni}$. This might be the result of trapping $\mathrm{Ni}$ atoms inside the anatase lattices and the formation of amorphous nickel oxide on the crystallite surfaces.

The BET surface areas and textural properties of the Ni-Ti-O mixed-oxide catalysts were evaluated using $\mathrm{N}_{2}$ adsorption/desorption measurements; the results are listed in Table 1. As the Ni content increases, the surface area of the catalyst first increases and then decreases. The BET surface area of the $\mathrm{Ni}_{2} \mathrm{Ti}_{1}$ catalyst is the highest, namely $182 \mathrm{~m}^{2} / \mathrm{g}$. The average pore diameters of the four catalysts are slightly different from each other, and all the catalysts are mesoporous materials. The surface areas of the Ni-Ti-O mixed-oxide catalysts with an anatase crystalline phase are higher than that of commercial anatase (47 $\mathrm{m}^{2} / \mathrm{g}$ ) [6]. These catalysts could therefore supply more available active binding/sorption sites, which is beneficial to catalytic reactions.

According to previous studies [4-9], the Lewis acidity plays an important role in SCR by hydrocarbons. Chemisorption of pyridine followed by FTIR spectroscopy was used to probe the nature of the surface acid sites on the Ni-Ti-O mixed-oxide catalysts; the results are displayed in Fig. 3. The concentrations of Lewis acid sites, Brönsted acid sites, and total acid sites are proportional to the strengths of the bands at 1448, 1540-1550, and $1490 \mathrm{~cm}^{-1}$, respectively [10]. With increasing Ni content, the concentration of Lewis acid sites first increased and then decreased, whereas the concentrations of Brönsted acid sites and total acid sites decreased significantly. The results show that the concentration of Lewis acid sites is in line with the catalytic performance. This observation and our previous results certify that the Lewis acid sites are the adsorption sites for $\mathrm{NO}$ in $\mathrm{C}_{3} \mathrm{H}_{6}-\mathrm{SCR}$ and are beneficial in enhancing the catalytic

Table 1

Surface areas, pore volumes, average pore diameters, Ni contents, and selectivities for $\mathrm{N}_{2}$ of Ni-Ti-O mixed-oxide catalysts.

\begin{tabular}{lcccrc}
\hline Sample & $\begin{array}{c}\text { Surface } \\
\text { area } \\
\left(\mathrm{m}^{2} / \mathrm{g}\right)\end{array}$ & $\begin{array}{c}\text { Pore } \\
\text { volume } \\
\left(\mathrm{cm}^{3} / \mathrm{g}\right)\end{array}$ & $\begin{array}{c}\text { Average pore } \\
\text { diameter } \\
(\mathrm{nm})\end{array}$ & $\begin{array}{c}\text { Ni con- } \\
\text { tent } \\
(\mathrm{wt} \%)\end{array}$ & $\begin{array}{c}\text { Selectivity for } \\
\mathrm{N}_{2}(\%)\end{array}$ \\
\hline $\mathrm{Ni}_{1} \mathrm{Ti}_{2}$ & 149 & 0.30 & 3.44 & 2.33 & 69.73 \\
$\mathrm{Ni}_{1} \mathrm{Ti}_{1}$ & 154 & 0.24 & 3.43 & 5.68 & 82.76 \\
$\mathrm{Ni}_{2} \mathrm{Ti}_{1}$ & 182 & 0.31 & 3.42 & 24.80 & 73.04 \\
$\mathrm{Ni}_{3} \mathrm{Ti}_{1}$ & 171 & 0.27 & 3.82 & 30.79 & 70.93 \\
\hline
\end{tabular}

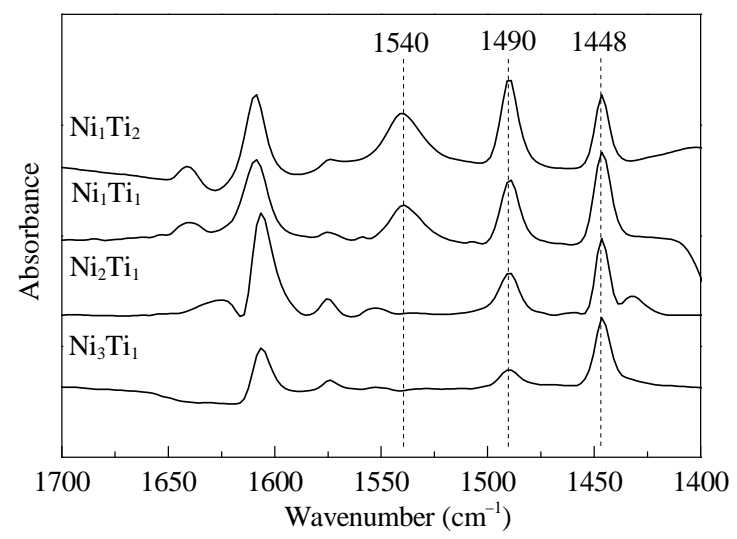

Fig. 3. FTIR spectra of pyridine adsorbed on Ni-Ti-O mixed-oxide catalysts.

performance [9]. Furthermore, the catalytic performance is not improved by increasing the concentration of Brönsted acid sites. It can therefore be concluded that Lewis acid sites are favorable for the catalytic performance in $\mathrm{C}_{3} \mathrm{H}_{6}-\mathrm{SCR}$, but the role of Brönsted acid sites is not clear.

\subsection{TPD and in-situ FTIR}

$\left(\mathrm{NO}+\mathrm{O}_{2}\right)$-TPD experiments were carried out to further analyze the adsorptive properties of the Ni-Ti-O mixed-oxide catalysts. Figure 4 shows the TPD profiles in $\mathrm{He}$ over the $\mathrm{Ni}_{1} \mathrm{Ti}_{1}$ and $\mathrm{Ni}_{3} \mathrm{Ti}_{1}$ catalysts; these display the highest and lowest catalytic performance, respectively. The desorption product detected below $150{ }^{\circ} \mathrm{C}$ is the result of physical adsorption [11], whereas the desorption species above $150{ }^{\circ} \mathrm{C}$ are ascribed to

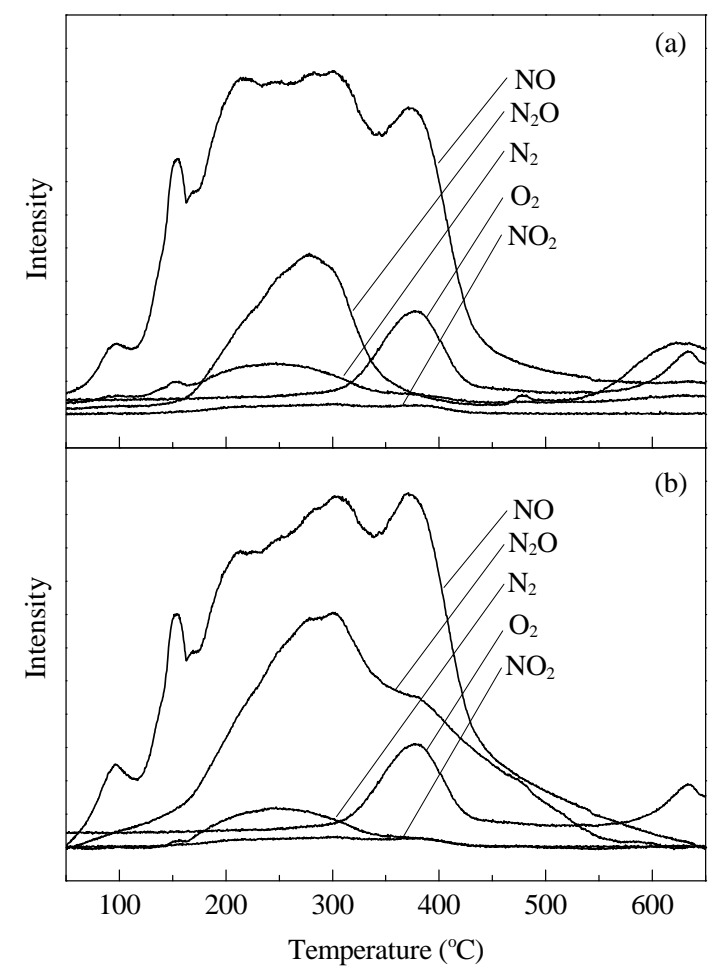

Fig. 4. $\left(\mathrm{NO}+\mathrm{O}_{2}\right)-\mathrm{TPD}$ profiles of $\mathrm{Ni}_{3} \mathrm{Ti}_{1}(\mathrm{a})$ and $\mathrm{Ni}_{1} \mathrm{Ti}_{1}$ (b) catalysts. 
chemical adsorption. The chemical adsorption of reactant is the basis and the prerequisite of catalytic reaction. NO is the main chemical desorption product for the two catalysts. They both exhibit a broad and high strength peak in the range 200-400 ${ }^{\circ} \mathrm{C}$. Desorbed $\mathrm{O}_{2}$ displays a peak centered at $390{ }^{\circ} \mathrm{C}$ over the two catalysts. However, the amount of desorbed $\mathrm{N}_{2} \mathrm{O}$ over the $\mathrm{Ni}_{1} \mathrm{Ti}_{1}$ catalyst is larger than that over the $\mathrm{Ni}_{3} \mathrm{Ti}_{1}$ catalyst, and the temperature window is broader. For the two catalysts, it is noteworthy that the desorption peaks of $\mathrm{NO}$ and $\mathrm{O}_{2}$, centered at $390{ }^{\circ} \mathrm{C}$, have similar shapes, but the amounts of these species over the $\mathrm{Ni}_{1} \mathrm{Ti}_{1}$ catalyst are larger. This desorption temperature is the optimal reaction temperature for $\mathrm{C}_{3} \mathrm{H}_{6}-\mathrm{SCR}$, and the catalytic activity of the $\mathrm{Ni}_{1} \mathrm{Ti}_{1}$ catalyst is higher than that of $\mathrm{Ni}_{3} \mathrm{Ti}_{1}$. These results suggest that an adsorbed species contributing to the desorption of $\mathrm{NO}$ and $\mathrm{O}_{2}$ is the intermediate for $\mathrm{C}_{3} \mathrm{H}_{6}-\mathrm{SCR}$. The simultaneous desorption of $\mathrm{NO}$ and $\mathrm{O}_{2}$ is caused by the adsorption nitrate $\left(\mathrm{NO}_{3}{ }^{-}\right)$[12], which acts as an important intermediate species for $\mathrm{C}_{3} \mathrm{H}_{6}-\mathrm{SCR}$.

To elucidate if the nitrate is the important intermediate of the reactivity, in-situ FTIR experiments were conducted to determine the adsorbed species and key species during the reaction. Figure 5(a) shows the in-situ FTIR spectra for adsorbed $\mathrm{NO}$ and $\mathrm{O}_{2}$ over the $\mathrm{Ni}_{3} \mathrm{Ti}_{1}$ catalyst. The characteristic peaks at

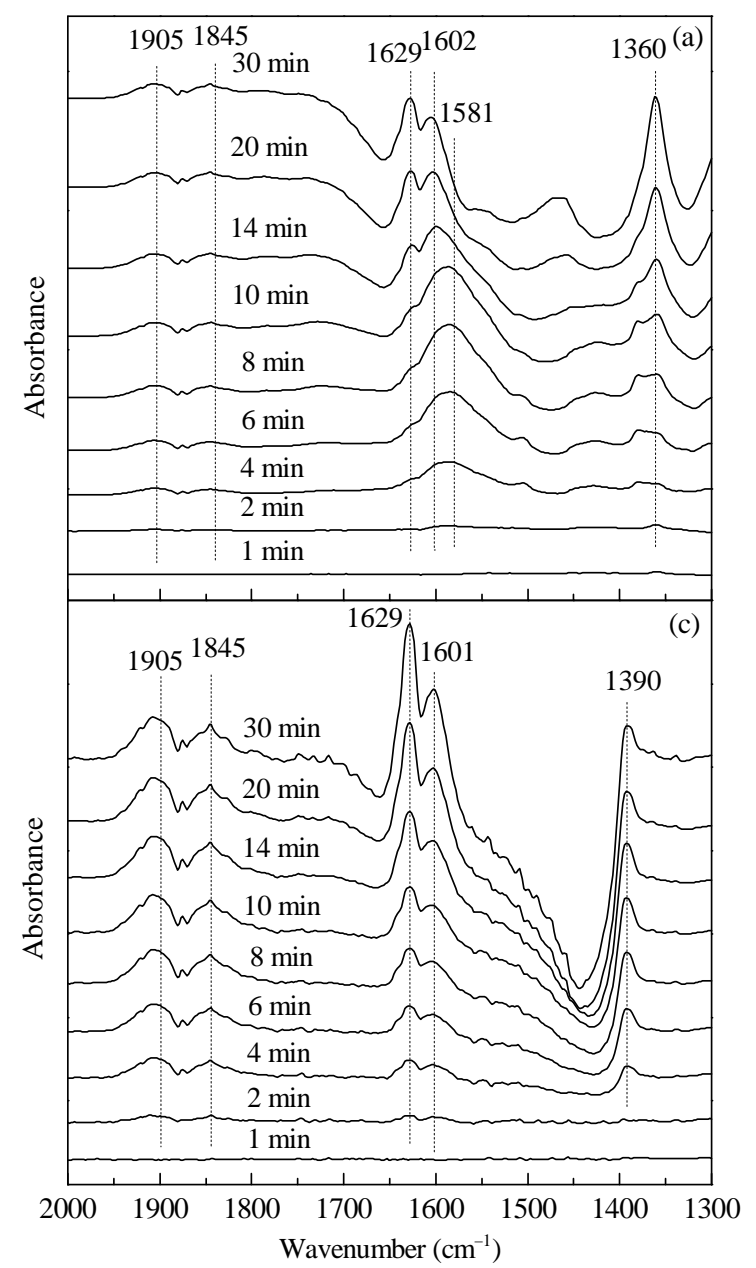

1905 and $1845 \mathrm{~cm}^{-1}$ arise from surface N0-. The bands at 1629 and $1602 \mathrm{~cm}^{-1}$ are assigned to bidentate bridging nitrate. The peak at $1581 \mathrm{~cm}^{-1}$ is attributed to monodentate nitrate. The bands at $1360-1390 \mathrm{~cm}^{-1}$ are ascribed to nitrate anions $\left(\mathrm{NO}_{3}{ }^{-}\right)_{2}$ [13-16]. The monodentate nitrate product decomposes gradually with time on stream, indicating that monodentate nitrate is unstable under the reaction conditions. In the case of the $\mathrm{Ni}_{1} \mathrm{Ti}_{1}$ catalyst (Fig. 5(c)), the same products are formed during the coadsorption process, except for the absence of monodentate nitrate. These nitrates are Lewis bases, which are electron donors. The Lewis acid sites are coordinatively unsaturated cationic metal sites, which are electron acceptors. The nitrates can therefore be adsorbed on the Lewis acid sites [12].

Switching the feed gas to $\mathrm{C}_{3} \mathrm{H}_{6}$ resulted in disappearance of the nitrates (Fig. 5 (b) and (d)), and formate (1377 and 1505 $\left.\mathrm{cm}^{-1}\right)$ and absorbed $\mathrm{C}_{3} \mathrm{H}_{6}\left(1505 \mathrm{~cm}^{-1}\right)$ were detected over the two catalysts. Moreover, acetate $\left(1578 \mathrm{~cm}^{-1}\right)$ appeared over the $\mathrm{Ni}_{3} \mathrm{Ti}_{1}$ catalyst $[16,17]$. According to a previous study [17], surface $\mathrm{NO}^{-}$cannot be reacted with catalyst directly, therefore the disappearance of surface $\mathrm{NO}^{-}$might be caused by reaction of $\mathrm{NO}^{-}$and $\mathrm{O}_{2}$. The in-situ FTIR results show that the nitrate species are intermediates in $\mathrm{C}_{3} \mathrm{H}_{6}-\mathrm{SCR}$ over the $\mathrm{Ni}-\mathrm{Ti}-\mathrm{O}$

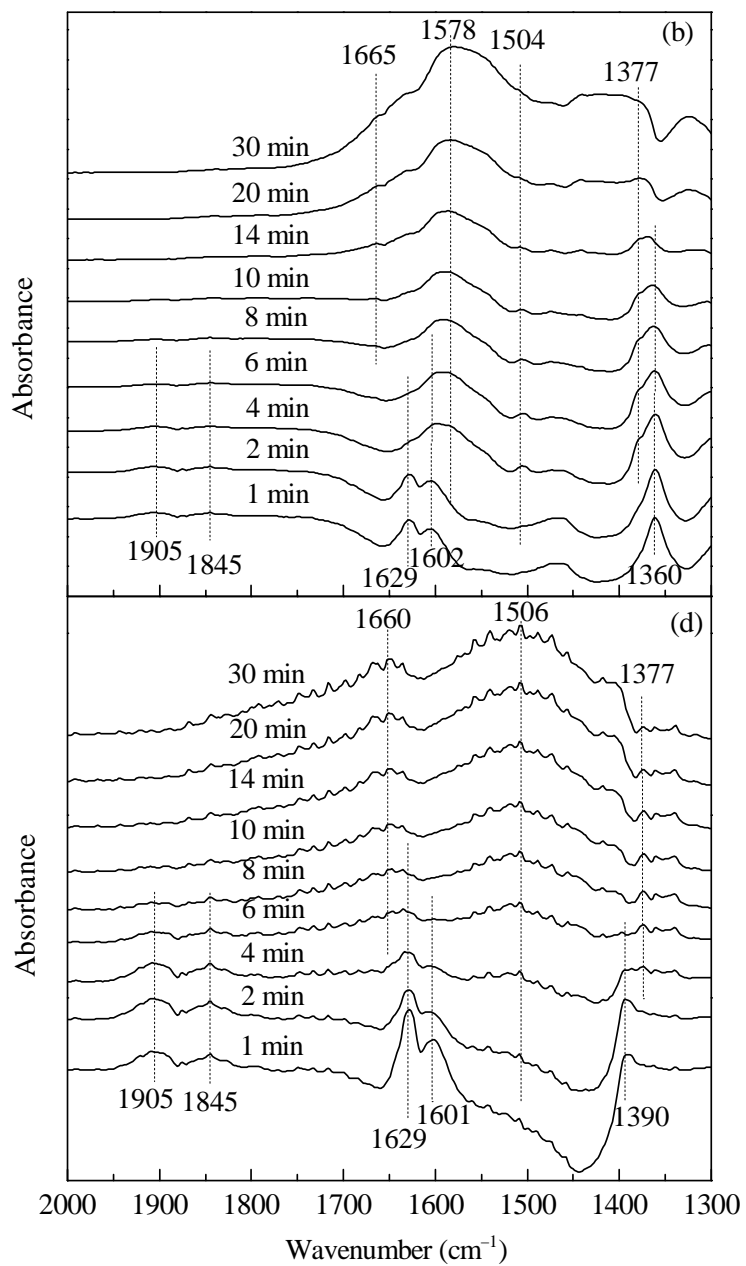

Fig. 5. In-situ FTIR spectra over $\mathrm{Ni}_{3} \mathrm{Ti}_{1}(\mathrm{a}, \mathrm{b})$ and $\mathrm{Ni}_{1} \mathrm{Ti}_{1}(\mathrm{c}, \mathrm{d})$ mixed-oxide catalysts without $\left(\mathrm{a}, \mathrm{c}\right.$ ) and with (b, d) exposure to $0.1 \% \mathrm{NO}+10 \% \mathrm{O}_{2}$ after switching to a flow of $0.1 \% \mathrm{C}_{3} \mathrm{H}_{6}+10 \% \mathrm{O}_{2}$. 


\title{
Graphical Abstract
}

Chin. J. Catal., 2013, 34: 1449-1455 doi: 10.1016/S1872-2067(12)60614-7 Preparation and characterization of $\mathrm{Ni}-\mathrm{Ti}-\mathrm{O}$ mixed oxide for
selective catalytic reduction of NO under lean-burn conditions

YUAN Deling, LI Xinyong*, ZHAO Qidong

Dalian University of Technology

A novel Ni-Ti-O mixed-oxide catalyst was used in the selective catalytic reduction of $\mathrm{NO}$ by $\mathrm{C}_{3} \mathrm{H}_{6}$ under lean-burn conditions; the catalyst demonstrated good activity at $430^{\circ} \mathrm{C}$.

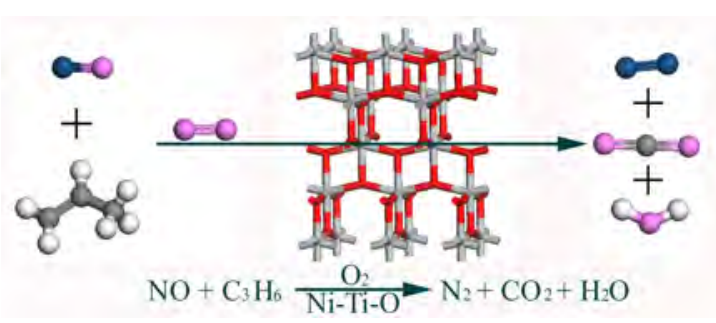

mixed-oxide catalysts and can react with $\mathrm{C}_{3} \mathrm{H}_{6}$. Monodentate nitrate was produced over the $\mathrm{Ni}_{3} \mathrm{Ti}_{1}$ catalyst, occupying the adsorption sites and being decomposed in the presence of excess $\mathrm{O}_{2}$, and it was not involved in the reaction of $\mathrm{C}_{3} \mathrm{H}_{6}-\mathrm{SCR}$, so it might be the reason that the catalytic performance of $\mathrm{Ni}_{3} \mathrm{Ti}_{1}$ was lower than that of $\mathrm{Ni}_{1} \mathrm{Ti}_{1}$. To sum up, both the TPD and FTIR results show that nitrate species are key intermediates for $\mathrm{C}_{3} \mathrm{H}_{6}$-SCR.

\section{Conclusions}

A series of environmentally friendly Ni-Ti-O mixed-oxide catalysts were prepared using a co-precipitation method. The catalyst with $\mathrm{Ni} / \mathrm{Ti}$ molar ratio of 1 exhibited good catalytic performance in $\mathrm{C}_{3} \mathrm{H}_{6}-\mathrm{SCR}$ at $430{ }^{\circ} \mathrm{C}$; the $\mathrm{NO}_{x}$ conversion reached $68 \%$. The catalyst structure changed with increasing $\mathrm{Ni}$ content in the catalysts, from an anatase structure to a mainly anatase structure with minor nickel oxide and nickel titanate phases. The catalysts had high surface areas (149-182 $\mathrm{m}^{2} / \mathrm{g}$ ). The TPD and in-situ FTIR results clarified the SCR reaction mechanism over the Ni-Ti-O mixed-oxide catalysts. Nitrate is an important intermediate in SCR, and high surface areas and Lewis acid sites are beneficial to nitrate adsorption. This study broadens research on non-noble-metal-oxide catalysts for SCR of $\mathrm{NO}_{x}$ in the presence of excess $\mathrm{O}_{2}$ and provides a theoretical foundation for the development of environmentally friendly deNO ${ }_{x}$ catalysts.

\section{References}

[1] Shan W P, Liu F D, He H, Shi X Y, Zhang C B. Appl Catal B, 2012, 115-116: 100

[2] Liu Z Q, Tang L, Chang L P, Wang J C, Bao W R. Chin J Catal (刘致强, 唐否, 常丽萍, 王建成, 鲍卫仁. 催化学报), 2011, 23:545

[3] Li G F, Wang X P, Jia C Y, Liu Z G. J Catal, 2008, 257: 291

[4] Mosqueda-Jiménez B I, Jentys A, Seshan K, Lercher J A. J Catal, 2003, 218: 375

[5] Liu F D, He H, Zhang C B, Feng Z C, Zheng L R, Xie Y N, Hu T D. Appl Catal B, 2010, 96: 408

[6] Zou X J, Li X Y, Zhao Q D, Chen G H. Chem J Chin Univ (邹学军, 李新 勇, 肇启东, 陈国华. 高等学校化学学报), 2012, 33: 1046

[7] Li N, Wang A Q, Zheng M Y, Wang X D, Cheng R H, Zhang T. J Catal, 2004, 225: 307

[8] Peña D A, Uphade B S, Smirniotis P G. J Catal, 2004, 221: 421

[9] Yuan D L, Li X Y, Zhao Q D, Zhao J J, Liu S M, Tadé M. Appl Catal A, 2013, 451: 176

[10] Kalita P, Gupta N M, Kumar R. J Catal, 2007, 245: 338

[11] Li X Y, Lu G, Qu Z P, Zhang D K, Liu S M. Appl Catal A, 2011, 398: 827

[12] Chmielarz L, Kustrowski P, Rafalska-Lasocha A, Majda D, Dziembaj R. Appl Catal B, 2002, 35: 195

[13] Chi Y W, Chuang S S C. J Catal, 2000, 190: 75

[14] Xu S C, Li J H, Yang D, Hao J M. J Phys Chem C, 2008, 112: 16052

[15] Captain D K, Amiridi M D. J Catal, 1999, 184: 377

[16] Shimizu K I, Satsuma A. Phys Chem Chem Phys, 2006, 8: 2677

[17] Jing G H, Li J H, Yang D, Hao J M. Appl Catal B, 2009, 91: 123

\section{Ni-Ti-O混合氧化物的制备、表征及其富氧选择性催化还原NO}

\author{
袁德玲, 李新勇, 肇启东 \\ 大连理工大学环境学院, 工业生态与环境工程教育部重点实验室, 精细化工国家重点实验室, 辽宁大连116023
}

\begin{abstract}
摘要: 采用均匀共沉淀法制备了不同 Ni/Ti摩尔比的 Ni-Ti-O混合氧化物, 考察了它们在富氧条件下丙烯选择性催化还原 NO反应 中的催化性能, 并运用 X射线衍射, $\mathrm{N}_{2}$ 吸附-脱附、吡啶吸附、程序升温脱附和原位红外光谱对催化剂进行了表征. 结果表明, $\mathrm{Ni} / \mathrm{Ti}$ 摩尔比为 1 的催化剂表现出最佳催化活性, $430{ }^{\circ} \mathrm{C}$ 时 $\mathrm{NO}_{x}$ 转化率达 $68 \%$. 该催化剂具有锐钠矿结构, 比表面积较高 $\left(149 \mathrm{~m}^{2} / \mathrm{g}\right)$, 有利 于提高催化活性; 其表面Lewis酸性位有利于硝酸盐物种的吸附, 而硝酸盐物种是该反应的重要中间体.
\end{abstract}

关键词: 镍钛混合氧化物; 选择性催化还原; 一氧化氮; 程序升温脱附

收稿日期: 2013-02-27. 接受日期: 2013-05-10. 出版日期: 2013-07-20.

*通讯联系人. 电话/传真: (0411)84707733; 电子信箱: xyli@dlut.edu.cn

基金来源：国家自然科学基金(21250110513, 51178076).

本文的英文电子版由Elsevier出版社在ScienceDirect上出版(http://www.sciencedirect.com/science/journal/18722067). 


\section{1. 前言}

随着汽车工业的快速发展和机动车保有量的逐年 增加, 其排放的氮氧化物 $\left(\mathrm{NO}_{x}\right)$ 污染引起了人们的高度 重视. 高效的贫燃发动机能显著减少能源的消耗, 有着 广阔的应用前景 ${ }^{[1]}$; 但是, 其排放的尾气中含有大量的 $\mathrm{O}_{2}$, 使得传统三效催化剂的催化活性大大降低 ${ }^{[2]}$. 因此, 开发能够在富氧条件下有效去除 $\mathrm{NO}_{x}$ 的催化剂具有重要 的理论和现实意义.

碳氢化合物选择性催化还原(SCR)技术被认为是消 除机动车尾气排放 $\mathrm{NO}$ 最有效的方法之一 ${ }^{[3]}$; 该法无需 额外添加还原剂, 具有巨大的应用潜力. 研究表明, $\mathrm{Ni}$ 基 催化剂对富氧条件下碳氢化合物SCR-NO反应表现出一 定的活性 ${ }^{[4]}$; $\mathrm{TiO}_{2}$ 因其廉价低毒而被广泛地用作 SCR 催 化剂载体 ${ }^{[5]}$. 因此, 本文采用尿素均匀共沉淀法制备了 $\mathrm{Ni}-\mathrm{Ti}$ 混合氧化物催化剂, 考察它在富氧条件下丙烯 -SCR NO反应中的催化性能, 并探讨了催化剂性能与结 构之间的关系.

\section{2. 实验部分}

\section{1. 催化剂的制备}

将一定量的 $\mathrm{Ni}\left(\mathrm{NO}_{3}\right)_{2} \cdot 6 \mathrm{H}_{2} \mathrm{O}$ 和 $\mathrm{Ti}\left(\mathrm{SO}_{4}\right)_{2}$ 加入到去离 子水中, 搅拌溶解, 配制成混合盐溶液; 再将尿素加入到 去离子水中, 搅拌溶解, 配制成尿素溶液. 然后, 将盐溶 液和尿素溶液混合(金属盐离子/尿素的摩尔比为3.3)、搅 拌, 加热至 $90^{\circ} \mathrm{C}$ 持续反应 $48 \mathrm{~h}$, 将离心分离所得沉淀物 水洗, 于 $70^{\circ} \mathrm{C}$ 干燥 $24 \mathrm{~h}, 450^{\circ} \mathrm{C}$ 焙烧 $6 \mathrm{~h}$, 即得 $\mathrm{Ni}-\mathrm{Ti}-\mathrm{O}$ 混 合氧化物催化剂, 分别记为 $\mathrm{Ni}_{1} \mathrm{Ti}_{2}, \mathrm{Ni}_{1} \mathrm{Ti}_{1}, \mathrm{Ni}_{2} \mathrm{Ti}_{1}$ 和 $\mathrm{Ni}_{3} \mathrm{Ti}_{1}$, 相应的 $\mathrm{Ni} / \mathrm{Ti}$ 摩尔比分别为 $0.5,1,2,3$.

\section{2. 催化剂的评价}

$\mathrm{C}_{3} \mathrm{H}_{6}-\mathrm{SCR} \mathrm{NO}$ 反应活性测试在固定床石英反应器 (直径 $6 \mathrm{~mm}$ ) 上进行. 催化剂用量 $0.2 \mathrm{~g}$. 反应气成分为 $0.1 \% \mathrm{NO}+0.1 \% \mathrm{C}_{3} \mathrm{H}_{6}+10 \% \mathrm{O}_{2}+\mathrm{He}$ (平衡气), 流量 100 $\mathrm{ml} / \mathrm{min}$. 尾气中 $\mathrm{N}_{2}$ 和 $\mathrm{C}_{3} \mathrm{H}_{6}$ 采用天美 $7980 \mathrm{II}$ 气相色谱在线 分析; 其中 $\mathrm{N}_{2}$ 的测定采用 $5 \mathrm{~A}$ 分子篮色谱柱和 TCD检测 器, $\mathrm{C}_{3} \mathrm{H}_{6}$ 的测定采用6DX-104色谱柱和FID检测器. NO 和 $\mathrm{NO}_{2}$ 浓度测定采用Testo 350型化学传感器多组分气体 分析仪. $\mathrm{N}_{2} \mathrm{O}$ 收率由 $\mathrm{NO}$ 转化率减去 $\mathrm{N}_{2}$ 和 $\mathrm{NO}_{2}$ 收率而得.

\section{3. 催化剂的表征}

催化剂的XRD谱采用LabX-6000型X射线粉末衍射 仪(日本岛津公司)测得 $\mathrm{Cu} K_{\alpha}$ 射线 $(\lambda=0.15406 \mathrm{~nm}$ ), 扫描 范围 $10^{\circ} \sim 80^{\circ}$, 扫描速度 $5^{\circ} / \mathrm{min}$. 催化剂的 $\mathrm{N}_{2}$ 吸附-脱附在
NOVA 4200e型气体吸附分析仪(美国康塔仪器公司)上 进行, 实验温度 $-198^{\circ} \mathrm{C}$.

催化剂的表面酸性使用吡啶吸附红外光谱(FTIR) 检测, 使用布鲁克公司VERTEX 70红外光谱仪测定, 取 $0.02 \mathrm{~g}$ 催化剂压成圆片, 真空加热至 $400{ }^{\circ} \mathrm{C}$ 预处理 $1 \mathrm{~h}$, 降 至室温后吸附吡啶 $20 \mathrm{~min}$ 至饱和, 再稳定 $30 \mathrm{~min}$. 最后, 在 $200^{\circ} \mathrm{C}$ 真空脱附吡啶并采集图谱.

\section{4. 程序升温脱附(TPD)和原位FTIR测试}

TPD实验在固定床反应器上进行, 尾气采用阿美特 克公司LC-D200M型质谱仪检测. 取 $0.1 \mathrm{~g}$ 催化剂在 $\mathrm{He}$ 气 中于 $250^{\circ} \mathrm{C}$ 预处理 $1 \mathrm{~h}$, 冷至室温后, 将入口气氛换为 $0.25 \% \mathrm{NO}+25 \% \mathrm{O}_{2}+\mathrm{He}$ (平衡气), 于室温下处理 $1 \mathrm{~h}$, 再 用 $\mathrm{He}$ 吹扫 $1 \mathrm{~h}$ 以去除表面物理吸附物种. 最后, 在He以 $10{ }^{\circ} \mathrm{C} / \mathrm{min}$ 升至 $650^{\circ} \mathrm{C}$. 原位 FTIR 实验在布鲁克公司 VERTEX 70型红外光谱仪上进行, 取 $0.02 \mathrm{~g}$ 样品压成圆 片, 于 $400^{\circ} \mathrm{C}$ 用 $\mathrm{He}$ 气预处理 $1 \mathrm{~h}$. 入口气体流量 40 $\mathrm{ml} / \mathrm{min}$.

\section{3. 结果与讨论}

\section{1. 催化剂活性评价}

图1为 Ni-Ti-O混合氧化物催化剂在富氧条件下 $\mathrm{C}_{3} \mathrm{H}_{6}$-SCR的催化性能. 由图可见, 随着反应温度的升高, $\mathrm{NO}_{x}$ 转化率先增加至最大值后下降; $\mathrm{C}_{3} \mathrm{H}_{6}$ 的转化率逐渐 增加至 $100 \%$, 此时 $\mathrm{NO}_{x}$ 转化率达最大值. 可见 $\mathrm{NO}_{x}$ 转化 率的下降是由缺少还原剂所致. 其中 $\mathrm{Ni}_{1} \mathrm{Ti}_{1}$ 催化剂上最 大 $\mathrm{NO}_{x}$ 转化率略高于其它催化剂, 操作温度窗口最宽, 且 最大转化率时 $\mathrm{N}_{2}$ 的选择性最高(见表1).

\section{2. 催化剂的表征结果}

图2为各Ni-Ti-O催化剂的XRD谱. 由图可见, 各催 化 剂均 在 $2 \theta=25.28^{\circ}, 37.80^{\circ}, 48.05^{\circ}, 55.06^{\circ}, 62.69^{\circ}$, $68.76^{\circ}$ 和 $75.03^{\circ}$ 处出现衍射峰, 对应于锐钛矿结构. 其中 $\mathrm{Ni}$ 含量较高的 $\mathrm{Ni}_{2} \mathrm{Ti}_{1}$ 和 $\mathrm{Ni}_{3} \mathrm{Ti}_{1}$ 催化剂还在 $2 \theta$ 为 $37.24^{\circ}$ 和 $43.36^{\circ}$ 处出现衍射峰, 分别对应于氧化镍和钛酸镍, 说明 它们为以锐钛矿结构为主, 且含有少量钛酸镍和氧化镍 的混合结构. 随着催化剂中 $\mathrm{Ni}$ 含量的增加, $\mathrm{Ni}$ 不断团聚 生成钠酸镍和氧化镍, 但是最终产物结构主要是锐钛矿. 这可能是由于这种均匀沉淀法导致镍进入到了锐钛矿 晶格内, 或者以无定形的形式分散在晶体表面.

表1为各Ni-Ti-O混合氧化物催化剂的比表面积、孔 体积和孔径. 由表可见, 随着 $\mathrm{Ni}$ 含量的增加, 催化剂的比 表面积先增大后减小, 其中以 $\mathrm{Ni}_{2} \mathrm{Ti}_{1}$ 催化剂的最大, 为 $182 \mathrm{~m}^{2} / \mathrm{g}$; 四种催化剂的孔径变化很小, 均属于介孔材 
料. 由于Ni-Ti-O混合氧化物催化剂的主要晶相是锐钛 矿, 而商品锐钛矿 $\mathrm{TiO}_{2}$ 比表面积为 $47 \mathrm{~m}^{2} / \mathrm{g}^{[6]}$, 可见, 本文 所制Ni-Ti-O混合氧化物具有较大的比表面积, 可以提供 更多的吸附位, 有利于催化反应的进行.

研究表明, 催化剂表面酸性在碳氢化合物SCR NO 反应中起到了重要作用. 本文采用吡啶作为探针检测催 化剂的表面酸性, 结果如图3所示. 位于 $1448 \mathrm{~cm}^{-1}$ 处红 外峰强度对应于Lewis酸含量, 1540 1550 $\mathrm{cm}^{-1}$ 处峰强度 对应Brönsted酸含量, $1490 \mathrm{~cm}^{-1}$ 处峰则对应催化剂表面 总酸含量 ${ }^{[10]}$. 由图可以看出, 随着 $\mathrm{Ni}$ 含量的增加, 催化 剂表面的Lewis酸量先增大后减小, Brönsted酸含量明显 减小, 因此总酸含量呈现出明显下降的趋势. 其中, Lewis酸性位是 $\mathrm{C}_{3} \mathrm{H}_{6}$-SCR NO的吸附位, 其含量与催化 活性呈正相关性 ${ }^{[9]}$; 而Brönsted酸含量明显增加时, 催化 活性未见明显提高. 这再一次说明, Lewis酸在富氧 $\mathrm{C}_{3} \mathrm{H}_{6}-\mathrm{SCR}$ 反应中有着重要的作用, 而Brönsted酸的作用 尚不清楚.

\subsection{TPD和原位FTIR结果}

为了进一步考察 Ni-Ti-O混合氧化物催化剂的吸附 性能, 图4给出了催化活性最高和最低的 $\mathrm{Ni}_{1} \mathrm{Ti}_{1}$ 和 $\mathrm{Ni}_{3} \mathrm{Ti}_{1}$ 催化剂上共吸附 $\mathrm{NO}$ 和 $\mathrm{O}_{2}$ 后在 $\mathrm{He}$ 中的TPD谱. 当温度低 于 $150{ }^{\circ} \mathrm{C}$ 时, 脱附物可认为是由物理吸附所致 ${ }^{[11]}$; 高于 $150^{\circ} \mathrm{C}$ 时的脱附物则被认为是由化学吸附引起的. 反应 物的化学吸附是催化反应的基础和前提. 由图可见, 两 种催化剂的主要化学吸附的脱附物种是 NO, 且均在 $200 \sim 400{ }^{\circ} \mathrm{C}$ 时出现一个强度低且宽的 $\mathrm{N}_{2}$ 脱附峰, $390{ }^{\circ} \mathrm{C}$ 时出现 $\mathrm{O}_{2}$ 的脱附峰, 其中 $\mathrm{Ni}_{1} \mathrm{Ti}_{1}$ 催化剂上 $\mathrm{N}_{2} \mathrm{O}$ 的脱附峰 强度更高, 且温度窗口更宽. 值得注意的是, 在脱附温度 为 $390{ }^{\circ} \mathrm{C}$ 时, 两种催化剂上同时出现了明显的 $\mathrm{NO}$ 和 $\mathrm{O}_{2}$ 脱 附峰, 峰形相似, 但 $\mathrm{Ni}_{1} \mathrm{Ti}_{1}$ 催化剂上 $\mathrm{NO}$ 和 $\mathrm{O}_{2}$ 的脱附量更 大. 结合图1发现, $\mathrm{NO}_{\text {和 }} \mathrm{O}_{2}$ 同时脱附的温度是催化反应 的最佳温度, 且 $\mathrm{Ni}_{1} \mathrm{Ti}_{1}$ 催化剂的催化活性高于 $\mathrm{Ni}_{3} \mathrm{Ti}_{1}$ 催化 剂. 由此可见, 引起 $\mathrm{NO}$ 和 $\mathrm{O}_{2}$ 同时脱附的物种是 $\mathrm{C}_{3} \mathrm{H}_{6}$-SCR NO反应的重要中间体. 研究表明 ${ }^{[12]}$, $\mathrm{NO}$ 和 $\mathrm{O}_{2}$ 的同时脱附是由吸附的硝酸盐引起的 ${ }^{[12]}$, 后者是 $\mathrm{C}_{3} \mathrm{H}_{6}$-SCR NO反应的重要中间体.

为了验证吸附的硝酸盐是否为反应的重要中间体, 图5(a)给出了 $\mathrm{Ni}_{3} \mathrm{Ti}_{1}$ 氧化物催化剂共吸附 $\mathrm{NO}$ 和 $\mathrm{O}_{2}$ 的FTIR 谱. 图中 1905 和 $1845 \mathrm{~cm}^{-1}$ 处峰可归属为 $N O$ 的气态吸附 $\left(\mathrm{NO}^{-}\right)$; 1629 和 $1602 \mathrm{~cm}^{-1}$ 处峰归属于二齿桥式硝酸盐; $1581 \mathrm{~cm}^{-1}$ 处峰可归属于单齿硝酸盐; $1360 ~ 1390 \mathrm{~cm}^{-1}$ 处 峰则对应于离子态的硝酸盐 $\left(\mathrm{NO}_{3}{ }^{-}\right)_{2}{ }^{[13 \sim 16]}$. 由图可见, 单 齿硝酸盐随吸附时间的延长而逐渐分解, 表明单齿硝酸 盐在反应条件下不稳定. $\mathrm{Ni}_{1} \mathrm{Ti}_{1}$ 催化剂(图5(c))上共吸附 $\mathrm{NO}$ 和 $\mathrm{O}_{2}$ 的产物与 $\mathrm{Ni}_{3} \mathrm{Ti}_{1}$ 催化剂类似, 只是并未检测到单 齿硝酸盐. 这些硝酸盐属于Lewis碱, 是电子供体. Lewis酸是由配位体中心的金属原子引起的, 是电子受体. 因此, 这些硝酸盐可以被吸附在Lewis酸位上 ${ }^{[12]}$.

当入口处气体改为 $\mathrm{C}_{3} \mathrm{H}_{6}$ (见图5(b)和(d)), 两种催化 剂上硝酸盐的谱峰逐渐消失, 同时生成甲酸盐(1377和 $\left.1505 \mathrm{~cm}^{-1}\right)$ 和吸附态 $\mathrm{C}_{3} \mathrm{H}_{6}\left(1505 \mathrm{~cm}^{-1}\right)$, 在 $\mathrm{Ni}_{3} \mathrm{Ti}_{1}$ 催化剂上 还检测到了乙酸盐 $\left(1578 \mathrm{~cm}^{-1}\right)^{[16,17]}$. 由于气态吸附的 $\mathrm{NO}^{-}$不能直接反应, $\mathrm{NO}^{-}$吸收峰的逐渐消失可能是 $\mathrm{NO}^{-}$ 与 $\mathrm{O}_{2}$ 反应所致. 上述结果表明, 在富氧条件下 $\mathrm{NO}$ 在 Ni-Ti-O混合氧化物催化剂表面上生成了硝酸(二齿桥式 和离子态硝酸盐), 它们是 SCR反应的中间体, 可以和氧 化的 $\mathrm{C}_{3} \mathrm{H}_{6}$ 发生反应. 在 $\mathrm{Ni}_{3} \mathrm{Ti}_{1}$ 催化剂上还生成了单齿硝 酸盐, 此物种占据了催化剂的吸附位, 在富氧条件下会 发生分解, 并未参与 $\mathrm{C}_{3} \mathrm{H}_{6}-\mathrm{SCR}$ 反应. 这也可能是 $\mathrm{Ni}_{3} \mathrm{Ti}_{1}$ 催化活性低于 $\mathrm{Ni}_{1} \mathrm{Ti}_{1}$ 的原因. TPD和原位FTIR结果均说 明, 硝酸盐是 $\mathrm{C}_{3} \mathrm{H}_{6}-\mathrm{SCR}$ 反应的重要中间体.

\section{4. 结论}

采用均匀共沉淀法制备了一系列环境友好型的 $\mathrm{Ni}-\mathrm{Ti}-\mathrm{O}$ 氧化物催化剂. 其中 $\mathrm{Ni}_{1} \mathrm{Ti}_{1}$ 催化剂在 $430{ }^{\circ} \mathrm{C}$ 表现 出最佳的 $\mathrm{C}_{3} \mathrm{H}_{6}-\mathrm{SCR} \mathrm{NO}$ 性能, $\mathrm{NO}_{x}$ 转化率达 $68 \%$. 随着 $\mathrm{Ni}$ 含量的增加, 催化剂中除以锐钛矿为主外, 还含有少量 氧化镍和钛酸镍的混合结构, 这些催化剂表现出较高的 比表面积. TPD和原位FTIR结果很好地说明了 Ni-Ti-O 氧化物催化剂上选择性催化还原的反应机理, 硝酸盐是 反应的重要中间体, 高的比表面积和较多的表面Lewis 酸位均有利于硝酸盐的吸附. 该结果拓宽了非贵金属氧 化物催化剂用于富氧条件下尾气脱硝的思路, 为进一步 开发高效的环境友好型脱硝催化剂提供了理论依据. 